\title{
PACAP upsets stomach theory
}

\section{Stephen A. Wank}

J. Clin. Invest. 104:1341-1342 (1999).

Notation labels for Figure 1 were moved in such a way that the figure may have been confusing to readers. The corrected figure appears below. Our apologies for the error.

\section{Figure 1}

Cephalic (neural) and peripheral (gastric and intestinal) endocrine and paracrine regulation of gastric acid secretion. $G, G$ cell; $P$, parietal cell; D, D cell; M cell, mucus cell; ENS, enteric nervous system; GRP, gastrin-releasing peptide; GRPR, GRP receptor; SMS, somatostatin; VIP, vasoactive intestinal polypeptide; $M$, muscarinic receptor; $\mathrm{M}_{3}$, muscarinic receptor type 3; SST2, somatostatin type 2 receptor; CCKA and CCKB, cholecystokinin type A and B receptors; $Y_{1}, P Y$ type 1 receptor; PY, peptide $Y$; $H 2$, histamine type 2 receptor; Gal1, galanin type 1 receptor. Green lines indicate stimulation; red lines indicate inhibition.
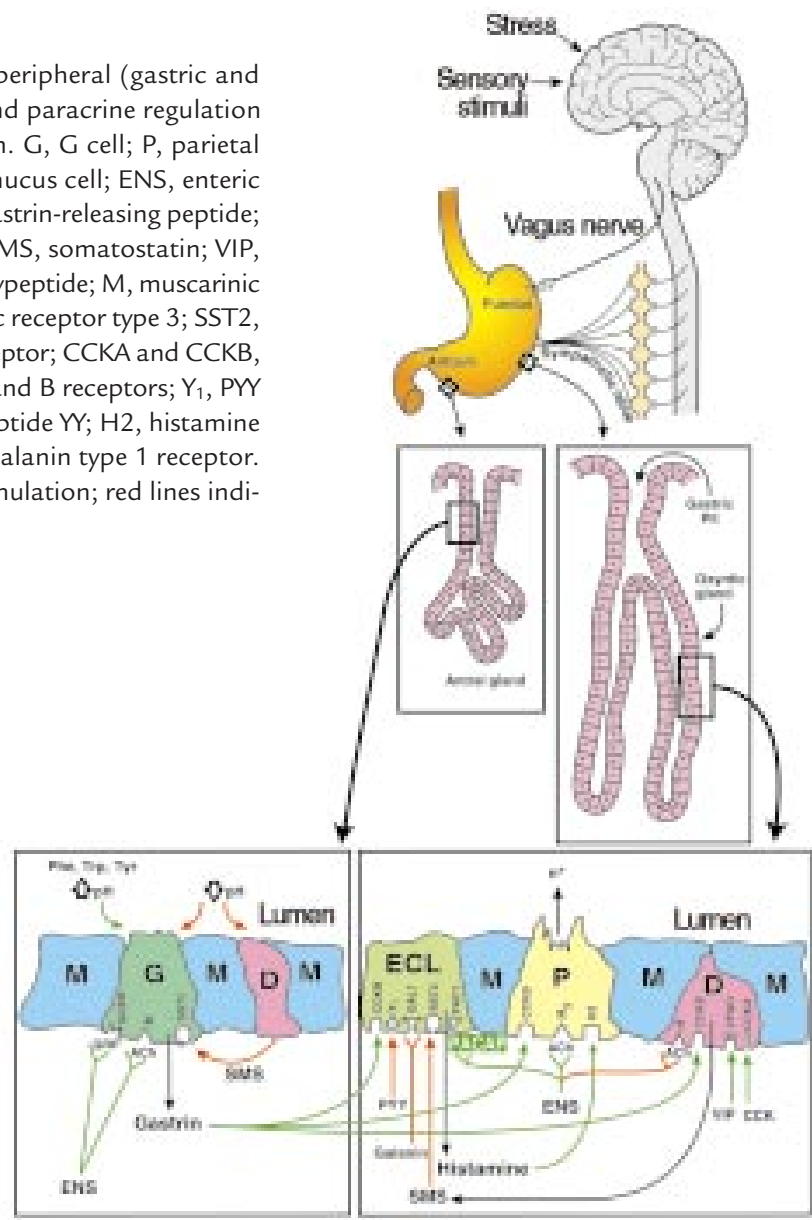